UDC: $316.46: 159.9$

http://doi.org/10.21272/mmi.2019.1-13

JEL Classification: M10, M12

Osman Uslu,

D.Sc., Sakarya University, Turkey

\title{
A GENERAL OVERVIEW TO LEADERSHIP THEORIES FROM A CRITICAL PERSPECTIVE
}

Abstract. Leadership still seems to be a popular theme among various disciplines and researchers as it was in the past. A growing body of research has been produced in the leadership field until now. Although increased studies and publications help to build up the leadership theory, leadership theory has not been integrated yet. The theoretical studies related to a specific field in a specific time seem to be useful in related field's advancement. With this rationale in this study, it is aimed to examine the prominent leadership theories in the literature. It is possible to specify the theories examined in the study as the Great Man Theory, Trait Theory, Behavioural Theory and Contingency Theory. So, firstly leadership theories have been divided into two as universal and contingency, and then, the basic assumptions and criticisms of each theory have been presented. Moreover, the findings of the models and researches that make up the theories have been presented in detail. In particular, comments on the criticisms of the theories have been made and a critical point of view has been tried to be reflected. According to findings, Great Man theory and Trait Theory were found to be clearly distinct theories from each other even they were considered together in most part of literature. Great Man Theory has been criticized since it has a gender-based prejudice. This was found very heavy criticism due to the nature of time in which women were not as active as men. Although Great Man and Trait Theories are criticized for lack of scientific research, they are accepted as the first theories in which leadership was examined scientifically. In fact, this is also a subject for major criticism. Because it is a great contradiction to scientifically judge these theories, which are supposed to be the first theories to examine leadership scientifically. Moreover, when all the theories including contingency theory are examined, the biggest criticism can be directed to the fact that a huge proportion of the leadership theories are of North American origin. The assumption that the findings of these researches in North American origin are valid in all parts of the world requires considering all theories with suspicion. In addition, there may be more than one hundred leadership styles today. Most of these new types of leadership, in fact, do not say much about anything new outside of the old ones and are repeating each other. A general overview of prominent leadership theories from a critical perspective has been presented in the study. Thus, it is expected to contribute to leadership, organizational behaviour and management literature.

Keywords: leadership, Great Man Theory, Trait Theory, Behavioural Theory, Contingency Theory.

Introduction. Leadership has long been of interest of studies and researches (Bennis, 2007), due to its nature of emphasis on people and groups. In some recent studies, it is claimed that leadership has been handed over since human beings' existence. Nowadays, it still seems to be a popular issue among various disciplines and researchers. Moreover, the number of journals addressing the leadership issue has increased in the last years. Although increased studies and publications help to build up the leadership theory, it is seen that leadership theory has not been integrated yet (Avolio, 2007). Especially, from the 1980s a huge number of leadership styles have emerged. This situation has been criticized by various theoreticians and academics in terms of the idea that new leadership styles are a form of self-replicating of the old theories. Another problem with leadership theories is that the leadership theories and the results of research in these theories differ in different local varieties of literature for reasons such as wrong translations or insufficient focuses. For instance, the results of Oxford and Michigan Universities' leadership studies in behavioural theory may be different in distinct publications even in the same local literature. These inconsistencies lead to incorrect progress of leadership knowledge and misunderstanding the leadership theories among scholars. Eradicating and eliminating mistakes is pivotal in terms of accurate scientific progression. Especially the summary type of studies related to a specific field in a specific time seems to be useful in related field's advancement since theoretical integration is still needed

Cite as: Uslu, O. A. (2019). General Overview to Leadership Theories from a Critical Perspective. Marketing and Management of Innovations, 1, 161-172. http://doi.org/10.21272/mmi.2019.1-13 
in leadership literature (Derue et al., 2011). For this purpose and reason in this study, it is aimed to present a general overview of leadership theories from classical to modern in a summary manner with a critical perspective. Prominent theories have been presented with their basic assumptions, features and criticisms in separate subtitles. By this way, it is aimed to make a contribution to leadership, organizational behaviour and management literature.

Literature Review. Different classifications of leadership theory exist in various publications such as books, articles or proceedings. Almost in all publications, it has been given place to contingency and behavioural theories of leadership. However, for instance, in some studies, no place has been given to Great Man Theory. Despite, everything in general, based on their basic assumptions it is possible to divide leadership theories into two categories as universal and contingency theories (Jago, 1982). Universal theories' assumptions suppose that leadership features, abilities or behaviours are valid anywhere and any condition. According to universal theories, effective leadership is something based on possessing some distinct qualifications or behaviours. On the other hand, in contingency theories, conditions and situations come into prominence. Effective leadership is something based on contingencies (Fiedler, 1975) such as the structure of the task, leader's position power or readiness' of followers. Effective leadership changes as conditions change and there is no universality. All prominent leadership theories are summarized in Table 1.

Table 1. Summary of Leadership Theories

\begin{tabular}{|c|c|c|c|c|c|}
\hline \multicolumn{3}{|c|}{ Universal Theories } & \multicolumn{3}{|c|}{ Contingency Theories } \\
\hline \multicolumn{3}{|c|}{1} & \multicolumn{3}{|r|}{2} \\
\hline & Assumptions & Criticisms & & Assumptions & Criticisms \\
\hline 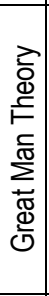 & $\begin{array}{l}\text { The leader has innate } \\
\text { characteristics. } \\
\text { Leadership is genetic. } \\
\text { Great men are natural } \\
\text { leaders. }\end{array}$ & $\begin{array}{l}\text { Has a gender-based } \\
\text { prejudice. Does not say } \\
\text { anything about } \\
\text { organizations. Lack of } \\
\text { scientific rigour and } \\
\text { reality. }\end{array}$ & & $\begin{array}{l}\text { In any case (under all } \\
\text { circumstances) there } \\
\text { is no optimal } \\
\text { leadership style. } \\
\text { Different situations } \\
\text { and circumstances } \\
\text { require different } \\
\text { leadership styles. }\end{array}$ & $\begin{array}{c}\text { The lack of adequate } \\
\text { research. } \\
\text { Fails to account for how } \\
\text { certain demographic } \\
\text { characteristics (e.g. } \\
\text { education, experience, age } \\
\text { and gender) influence the } \\
\text { leader-subordinate relations. }\end{array}$ \\
\hline \multirow[b]{2}{*}{ 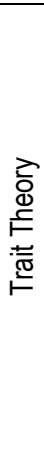 } & \multirow[b]{2}{*}{$\begin{array}{c}\text { The leader has a } \\
\text { whole set of congenital } \\
\text { and subsequently } \\
\text { acquired } \\
\text { characteristics. }\end{array}$} & \multirow[b]{2}{*}{$\begin{array}{l}\text { Lack of empirical tests } \\
\text { and research. } \\
\text { Does not take into } \\
\text { account environmental } \\
\text { factors. } \\
\text { Inconsistent research } \\
\text { findings of leader } \\
\text { characteristics. } \\
\text { Does not provide clear } \\
\text { information for the } \\
\text { measurement of } \\
\text { characteristics. }\end{array}$} & \multicolumn{3}{|c|}{ Findings } \\
\hline & & & 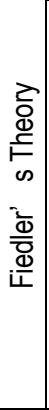 & $\begin{array}{r}\text { When the leader-follow } \\
\text { are planned or structure } \\
\text { high, the most effectiv } \\
\text { leadership. On the con } \\
\text { relations are weak, } \\
\text { unstructured, and the le } \\
\text { most effective leader } \\
\text { leadership. When the } \\
\text { moderate, the tasks } \\
\text { structured, and the lead } \\
\text { the most effective leade } \\
\text { le }\end{array}$ & $\begin{array}{l}\text { r relations are good, the tasks } \\
\text {, and leader's position power is } \\
\text { leadership is task motivated } \\
\text { rary, when the leader-follower } \\
\text { the tasks are unplanned or } \\
\text { der's position power is low, the } \\
\text { ship is still tasked motivated } \\
\text { leader-follower relations are } \\
\text { are moderately planned or } \\
\text { r's position power is moderate, } \\
\text { rship is relationship motivated } \\
\text { adership. }\end{array}$ \\
\hline 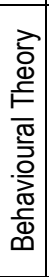 & $\begin{array}{l}\text { The effectiveness of the } \\
\text { leader depends on } \\
\text { his/her behaviours. } \\
\text { Leader behaviours are } \\
\text { not innate, can be seen } \\
\text { and learned, and } \\
\text { effective leaders can be } \\
\text { trained. }\end{array}$ & $\begin{array}{c}\text { Has inconsistencies } \\
\text { among the findings of the } \\
\text { research. } \\
\text { Does not consider } \\
\text { situational factors in } \\
\text { explaining leadership }\end{array}$ & 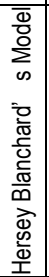 & $\begin{array}{r}\text { When it is considered } \\
\text { work maturity, if the fo } \\
\text { leadership style is } \\
\text { followers are immatur } \\
\text { telling style. If the } \\
\text { moderate, then effectiv } \\
\text { and part }\end{array}$ & $\begin{array}{l}\text { terms of psychological and } \\
\text { owers are mature effective } \\
\text { legating style and if the } \\
\text { effective leadership style is } \\
\text { llowers' maturity level is } \\
\text { leadership styles are selling } \\
\text { ipating styles. }\end{array}$ \\
\hline
\end{tabular}


Continue Table 1

\begin{tabular}{|c|c|c|c|}
\hline \multicolumn{2}{|r|}{1} & \multicolumn{2}{|r|}{2} \\
\hline & Findings & & \multirow{5}{*}{$\begin{array}{l}\text { In cases where tasks are uncertain and stressful, } \\
\text { directive leadership leads to high job satisfaction. } \\
\text { Supportive leadership results in high job satisfaction } \\
\text { and performance when tasks are certain (structured) } \\
\text { and planned. When a directive leadership style is } \\
\text { applied to employees with high experience and } \\
\text { competence, the reluctance of employees emerges. } \\
\text { While tasks are uncertain and complex, participative } \\
\text { leadership is the most effective leadership if group } \\
\text { members expect clarity and autonomy. While the } \\
\text { tasks are uncertain and complex, the achievement- } \\
\text { oriented leadership style is determined as the most } \\
\text { effective leadership if the expectations of the group } \\
\text { members are high. }\end{array}$} \\
\hline 끙 & $\begin{array}{l}\text { In the long run, the most effective leader } \\
\text { behaviour is democratic leadership. }\end{array}$ & & \\
\hline 을 & $\begin{array}{l}\text { The most effective leadership style is the } \\
\text { situation high initiating structure (task or job } \\
\text { oriented) and high consideration (relationship } \\
\text { or employee oriented) behaviours. }\end{array}$ & & \\
\hline 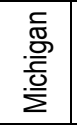 & $\begin{array}{l}\text { The most effective leadership style is } \\
\text { employee-oriented one. }\end{array}$ & & \\
\hline 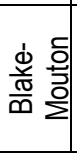 & $\begin{array}{l}\text { The most effective leadership is team } \\
\text { leadership, with the highest level of behaviours } \\
\text { concern for results (production) and concern } \\
\text { for people (employee). }\end{array}$ & & \\
\hline
\end{tabular}

Source: compiled by the author.

Great man theory, trait theory and behavioural theory take part in universal leadership theories. While great man theory and trait theory focus on physical, psychological or personality traits, behavioural theory pays attention to leader's behaviours in order to explain effective leaders.

Basic Assumption of Great Man Theory: What makes the leader a leader is that he/she has a set of innate characteristics. Leadership is genetic. Scientifically, leadership is known to begin with the Great Men Theory. The historian Thomas Charlyle was the pioneer of the great men theory (Allio, 2013). In his book, "On Heroes», which he wrote in 1841 (Mirzoeff, 2006), Charlyle examined the great people (Seigel, 1995) who lead a life (Van Wart, 2003) in all fields such as state administration, politics and religion. Fatih Sultan Mehmed, Napoleon, Prophet Muhammad, Jesus Christ, Alexander the Great, Winston Churchill are examples of great men. While the big men who lead the flow of life are considered leaders, the focus of theory is on the differences between the leaders and non-leaders (Carlyle, 1993). According to the theory, there is a unique set of features that distinguish great men from ordinary people (Carlyle, 1993). For instance, these features can be expressed as attractiveness, commandants, credibility, high initiative, reasoning ability, courage and action. The characteristics of the leader distinguish the leader from nonleader. The great men are natural leaders (Harrison, 2018) and they emerge as leaders in all conditions. The theory suggests that the anatomy, psychology and personality of great men are different from ordinary people. Therefore, not everyone can be a leader and cannot want to be a leader because leadership is seen as a gift from God to human beings (Spector, 2016). Furthermore, the characteristics of a leader are innate and pass through the gene. Thus, great man theory can also be called as the genetic theory. As the characteristics are genetic, leadership is something that cannot be learned, and leadership characteristics cannot be acquired afterwards. So, a human being either has these characteristics inborn or not. The theory of great men is criticized in some ways by theoreticians. One of these criticisms, as the name suggests, is that it involves a gender-based prejudice (Spector, 2016). In theory, male characteristics are often emphasized and masculine elements (Grint, 2011) are frequently included. There is a view that females can also be a leader and it is neglected in the theory. This may be a critical point of view, but it should not be ignored that the theory has a fair share. The origin of the theory coincided with the late 19th and early 20th centuries. As a matter of fact, women were not at the forefront in areas such as business, politics, religion and state administration in these years (Kirkpatrick and Locke, 1991). Or, for instance, the absence of a female prophet in history makes the theory rational. Therefore, it can be considered as a natural condition that the theory includes a gender-based prejudice. Another criticism is 
that the theory does not emphasize in any way the harmonization of people in organizations or in businesses (Grint, 2011).

This criticism is also congruent, but it should not be ignored that there were no large-scale businesses in the related period when the theory was revealed and that the fact that management was not accurately the subject of scientific investigations worldwide. It was also criticized that great men theory had an understanding of leadership independent of environmental factors and claimed that leadership characteristics were only passed through genes (Kirkpatrick and Locke, 1991). People have the idea that if leaders were not born, it would have manifested itself in people at early ages. Beyond that, if the leaders were born, other men from the descendants of the great men would also have been expected to be leaders. The last criticism of the theory is that it is far from scientific rigour and reality (Harrison, 2018). It is claimed that the assumptions of the theory are speculative. In this case, it can be considered natural because it is dealt with in a philosophical language. On the other hand, it is necessary to acknowledge that the theory lacks empirical studies. It should not be forgotten that the power of a scientific discipline or theory varies depending on the empirical studies, theoretical integration, academic widespread influence and the number and quality of publications in the field. Many recent modern leadership theorists and leaders deny the assumptions of the great men theory. Although there are criticisms about the theory, the number of people who believe that leadership is innate is still quite high nowadays.

Basic Assumption of Trait Theory: Leadership does not always come from birth and leadership characteristics can be gained and learned. What distinguishes the leader from other people is that the leader has a whole set of congenital and subsequently acquired characteristics. Criticisms addressed to the great men theory has led to the emergence of trait theory that claims leadership is not only a congenital, but a combination of both congenital (Pierce and Dunham, 1990) and acquired characteristics. In this respect, the trait theory is considered as a modification of the great men theory (Kirkpatrick and Locke, 1991). Accordingly, there is a need to explore the characteristics that make the leader and distinguish a leader from other people. Many researchers have demonstrated various leadership characteristics that explain leadership. In general, height, weight, gender, maturity, openness, persuasion, domination, knowledge, determination, self-confidence and forward vision are just some of them (Harrison, 2018; Stodgill, 1974; 1948). For instance, Mann (1959) made a list of 1400 features in explaining leadership. Stodgill (1948) examined leadership studies from 1904 to 1947 and then identified 124 leader characteristics. He then narrowed down and found 8 distinctive leadership characteristics. These characteristics are intelligence, intuition, responsibility, and sociability, insistence on dealing with problems, self-confidence and agility in meeting the needs of others. As it is seen, even most of the characteristics are acquired later, but they can also be innate characteristics such as gender and intelligence. In this sense, trait theory is distinguished from great men theory. It has a universal point of view as people with certain characteristics are leaders (Kirkpatrick and Locke, 1991). Stodgill (1974), on the other hand, argued that a person with the characteristics does not guarantee to be a leader.

According to him, although having certain characteristics does not guarantee leadership, the individual is more likely to be an effective leader and has a higher potential. The trait theory has been criticized in similar ways as the great men theory. First, it is emphasized that the assumptions of the theory are speculative, and the theory lacks empirical tests and research (Harrison, 2018). For instance, the theory cannot give a clear descriptive answer to the question of who the leader is. On the other hand, as in the great men theory, the trait theory is also criticized for having a narrow perspective. At this point, only leadership characteristics have been put forward in theory, but environmental factors (Robbins, 2001) such as the group values affecting the leadership and the structure of the tasks have not been taken into account. However, leadership is not a superficial phenomenon that can only be explained by characteristics. In addition to the lack of empirical tests and research (Harrison, 2018), there is also inconsistency between the characteristics set forth in the limited studies in trait theory (Judge et al., 2002). 
For instance, some studies focus on physical characteristics in explaining leadership, while others focus on internal characteristics such as personality. In addition, the factors that led to the leader's achievement in some studies have led to failure in other studies (Fleeor, 2006). This indicates that the studies are inconsistent in terms of their findings. Furthermore, the theory does not provide clear information for the measurement of characteristics (Bolden et al., 2003). Intelligence is a leadership trait, for instance, but the theory does not provide sufficient explanations about the intensity or degree of intelligence required to be a leader. In general, it is possible to summarize the biggest criticisms of the trait theory as ignoring the environmental conditions and factors and the inconsistency findings in studies (Schriesheim and Tolliver ve Behling, 2001). In addition, the assumptions of great men theory in many sources seem to be the same as the assumptions of trait theory. Although the origin of the theory is based on the great men theory (Kirkpatrick and Locke, 1991), one must not forget that there is, in fact, a difference between them in viewpoints of leadership characteristics. While the great men theory suggests leadership characteristics are innate, the trait theory states that these characteristics can be acquired both in birth and later. This distinction reveals that the two theories are separate theories but have some common assumptions.

Basic Assumption of Behavioural Theory: The effectiveness of the leader not depends on the characteristics of the leader but depends on his/her behaviour. Leader behaviours are not innate, can be seen and learned, and effective leaders can be trained. The inadequacy of the trait theory in determining effective leadership and the criticisms addressed to this theory have provided the basis for the emergence of behavioural theory (Harrison, 2018). According to the theory, rather than the personality characteristics of the leader, the effectiveness of a leader is related to how the leader behaves or what he/she does (Northhouse, 2010). Leader behaviour is not innate but can be learned afterwards (Goff, 2003). In this way, effective leaders can be trained. The way of communication with the subordinates, authority delegation, planning, control type or the way of purpose determined is just some of them. According to the theory, behaviours that bring the group to success bring along the success of the leader. In this respect, the leader is not unique to the individual, as in the great men and trait theories. The leader is not independent of the group and the effectiveness of the leader depends on his/her behaviours and the relationship with group members. It is emphasized that behaviours mentioned in the theory are not innate (Amanchukwu, et al., 2015), but especially subsequently acquired. And so, the idea is that leader behaviours can be learned and effective leaders can be trained (Goff, 2003). With this perspective, it was aimed to determine the behavioural differences between the effective and ineffective leaders in the studies that constitute the behavioural theory (Robbins, 2001). The basic studies in behavioural theory are lowa University Studies by Kurt Lewin and his friends, Ohio University Studies, Michigan University Studies (Nortcraft and Neale, 1990) and Blake and Mouton Managerial Diagram Model. In these studies, leader behaviours generally consist of being oriented towards job or task, being oriented towards relationship or employee, and a range of behaviours between these two (Derue et al., 2011; Daft, Kendrick and Vershinina, 2010).

Finding of lowa University Research: In the long run, the most effective leader behaviour is democratic leadership. In the 1930s, Kurt Lewin and his team did research on leadership behaviour at the University of lowa and aimed to determine the effective leader behaviours (Lewin et al. 1939). Three types of leadership style have been put forward in the studies which focused on the leadership style of managers (Engard, 2017). The autocratic leadership style is related to the task or job-oriented, and in this way, it is explained to the employees about what should be done. The democratic leadership style, on the other hand, is related to the orientation towards the relationship or the employee, and in this way, the participation of the employees in the decisions is encouraged. In laisses fair leadership, employees are never interfered and never intervened (Harrison, 2018). Kurt Lewin and his team observed in their research conducted on mask producing children that autocratic leadership style significantly increased production in the short term (Billig, 2015). However, it was observed that children behaved in a way that they tended 
not to consume much energy when autocratic and laisses fair leadership behaviours were shown to group members. In the long term, democratic leadership style was found to be most contributing to the production (Billig, 2015).

Finding of Ohio University Research: The most effective leadership style is the situation of high initiating structure (task or job oriented) and high consideration (relationship or employee oriented) behaviours. The Ohio University research conducted on civilian and military personnel aiming to determine the effects of leadership styles on group members firstly identified approximately 1800 leader behaviours. Then these 1800 behaviours were reduced to 150 dimensions and finally to the 2 basic dimensions independent of each other. These dimensions can be specified as consideration and initiating structure (Robbins, 2001). Consideration refers to the need for our understanding of human relations and is related to employee needs (Schriesheim, et al., 2001; Griffin, 1990). On the other hand, the initiating structure refers to the task while dealing with the needs of the organization (Daft, et al.,2010; Gordon, 1991). In the research, it is assumed that the two behavioural dimensions are independent of each other, where a leader can display both behaviours simultaneously at high or low levels (Daft, et al., 2010). According to the findings of the research, the most effective leadership style has been determined as the situation where both the initiating structure (task-oriented) and consideration (relationship-oriented) behaviours are high.

Finding of Michigan University Research: the most effective leadership style is employee-oriented one. In a series of research conducted at the University of Michigan under the direction of Rennis Likert, it was aimed to determine the most appropriate leadership behaviour that had an impact on the productivity and satisfaction of the group members (Johns and Moser, 2001). As Ohio University research, two types of leadership have been identified in the research, namely production oriented and employee oriented (Likert, 1979). Unlike Ohio University research, the leadership styles put forward here are not independent of each other (Daft, et al., 2010). According to this, a leader cannot be both production and employee oriented. The more a leader exhibits employee-oriented behaviour, the more he/she moves away from productionoriented behaviour. This difference is the most fundamental distinction between Ohio and Michigan research. In addition, according to the findings of the University of Michigan research, the most effective leadership was employee-oriented leadership. Finding of Blake and Mouton Managerial Diagram Model: the most effective leadership is team leadership, with the highest level of behaviours concern for results (production) and concern for people (employee). The model, known as the Blake and Mouton managerial diagram or management grid, was developed based on the results of the Ohio and Michigan University research. In the model, concern for results behaviour takes part in the horizontal axis between 1 to 9 and concern for people behaviour which takes part in the vertical axis is between 1 to 9 . Different leadership styles have been developed depending on the different combinations of two leadership behaviours (Daft, et al., 2010). Accordingly, the situation of the highest behavioural attitudes towards production and the lowest behavioural attitudes towards people $(9,1)$ is task management. In contrast, the situation of the lowest behavioural attitudes towards production and the highest behavioural attitudes towards people $(1,9)$ are country club management. The situation of both behavioural attitudes towards production and towards people lowest $(1,1)$ is impoverished. In contrast, the situation of both behavioural attitudes towards production and towards people with highest $(9,9)$ is team management. Finally, the situation of both behavioural attitudes towards production and towards people with midmost $(5,5)$ is middle of the road management (Harrison, 2018;) According to the model, the most effective leadership style is indicated as team leadership (Harrison, 2018; Robbins, 2001; Northcraft ve Neale, 1990).

As in the trait theory, major inconsistencies among the findings of the research have been also observed in behavioural theory (Gill 2011; Northouse 2010). This is one of the criticisms addressed towards behavioural theory. However, the biggest criticism of behavioural theory is that it does not consider situational factors in explaining leadership (Harrison, 2018; Barling et al., 2011). When the findings of the studies in behavioural theory are examined, it is seen that all of them have reached universal 
findings (Flocy, 2017; House and Aditya, 1997). For instance, the University of Michigan research shows that employee-oriented leadership is the most effective leadership, while the University of lowa research suggests that democratic leadership is the most effective leadership. The leadership styles that are claimed to be valid everywhere and under all circumstances, in fact, can be affected by the conditions. For instance, in organizations with employees with individualist cultural values that advocate equality and freedom, while the most effective leadership may be democratic leadership, it may not be in an organization with predominantly collective cultural values. Cultural values can be many environmental factors such as the level of maturity of the employees, the level of acceptance of the leader by the follower and the nature of the task. Leadership effectiveness can be affected by several environmental factors (Yukl, 1989), such as the level of maturity of the employees, the level of leader's acceptance by the followers, the nature of the task and employees' cultural values. Behavioural theory's failure to address those factors can be regarded as the most fundamental critique.

Basic Assumption of Contingency Theories: in any case (under all circumstances) there is no optimal leadership style. Different situations and circumstances require different leadership styles. Because of ignoring environmental factors in explaining what effective leadership is, criticisms addressed to great men, trait and behavioural theories have provided the basis for the emergence of contingency theory. In the emergence of contingency leadership theory factors such as lack of emphasis on conditions and environment affecting leadership (Harrison, 2018), insufficiency of universal leadership theories (Flocy, 2017) and the view that leadership cannot be explained by purely traits and behaviours have been effective. According to contingency leadership theory, the person may be an effective leader in certain conditions or environments, but the same person may not be the leader in other conditions or environments. Similarly, a leadership style that has been effective in the past may not be effective today (Fiedler, 2006). In fact, all this shows that there is no optimum leadership style in all cases and circumstances. For instance, in the early 1900 s effective leadership was an autocratic leadership, but nowadays autocratic leadership cannot be regarded as an effective leadership style in all over the world. In time, people's income status, understandings, culture or expectations may change. According to the theory, it is possible to talk about many factors that make the leadership style effective (Kraft, 2018). For instance, the personal characteristics of the leader, the characteristics of the followers or group, the structural characteristics of the organization, the nature of the objectives and the past experiences of the leaders and followers are some of these factors (Yukl, 1989). According to contingency theory, if effective leadership is a function, leadership behaviour and conditions are the basic elements of this function. There are many types of research, approaches and models that contribute to contingency leadership theory. Among these, Fielder's Contingency Theory, Path-Goal Theory and the Hersey-Blanchard Situational Leadership Model appear to be prominent.

Finding of Fiedler's Contingency Theory: When the leader-follower relations are good, the tasks are planned or structured, and leader's position power is high, the most effective leadership is task motivated leadership. On the contrary, when the leader-follower relations are weak, the tasks are unplanned or unstructured, and the leader's position power is low, the most effective leadership is still tasked motivated leadership. When the leader-follower relations are moderate, the tasks are moderately planned or structured, and the leader's position power is moderate, the most effective leadership is relationship motivated leadership. Fiedler sought answers for two basic questions. If one of the leaders with the same qualifications is effective, why is the other not effective under the same conditions? Why is a leader effective in one case, not active in the other case? Fiedler seeks to identify the conditions that make the leader effective when looking for answers to these questions (Daft, et al., 2010). He has identified 3 variables (conditions) that determine the effectiveness of the leader (Rue and Byars, 1990; Robbins, 2001; Northcarft and Neale, 1990). These conditions are the leader-follower relations (may be good, moderate or weak), the task structure (maybe structured/planned, moderately structured/moderately planned or 
unstructured/unplanned) and the position power of the leader (may be strong, moderate or weak). The good leader-follower relations mean that the follower has a high level of trust, love and respect towards the leader, while weak leader-follower relations mean that the follower has a low level of trust, love and respect towards the leader (Gordon, 1991). The structure of the task is related to the ways and methods of doing the work. If the tasks are planned/structured, the works are certain and clear. On the contrary, if the tasks are not planned/structured, the job is left to the person who will do the work and there is uncertainty (Northcarft and Neale, 1990). The leader's position power refers to the legal power of the leader in the managerial position (Yukl, 1989). In this context, power includes activities such as rewarding, punishment, promotion and dismissal. The strong leader in terms of position power holds the legal power at a high level while the weaker have the legal power at a low level. All these conditions together revealed various separate conditions (Fiedler, 2006). When the leader-follower relations are good, the tasks are planned or structured, and leader's position power is high, the most effective leadership is task motivated leadership. On the contrary, when the leader-follower relations are weak, the tasks are unplanned or unstructured, and the leader's position power is low, the most effective leadership is still tasked motivated leadership. When the leader-follower relations are moderate, the tasks are moderately planned or structured, and the leader's position power is moderate, the most effective leadership is relationship motivated leadership (Robbins and Judge 2012; Daft, et al., 2010). Because leadership behaviours are rigid, Fiedler has suggested that conditions should be adapted to the behaviour of leaders by training rather than applying the appropriate leadership style (Fiedler, 2006). Fiedler's theory has contributed to leadership in terms of providing a wide range of leadership behaviours, rather than a polarizing model. On the other hand, the theory has been criticized to be built on a lot of variables and data. Finding of HerseyBlanchard Situational Leadership Model: when it is considered in terms of psychological and work maturity if the followers are mature, effective leadership style is delegating style and if the followers are immature, effective leadership style is telling style. If the followers' maturity level is moderate, then effective leadership styles are selling and participating styles.

In the Hersey-Blanchard model, the maturity dimension was added to the previous dimensions, such as relationship-oriented and task-oriented behaviours. According to the model, determining the appropriateness of leader behaviour is based on maturity (readiness) of followers (Daft, et al., 2010; Robbins, 2001). The maturity mentioned here is not about age and emotional stability, but about the desires for success, skills and experiences of the followers. In this context, maturity is divided into two as psychological maturity and work maturity. While psychological maturity is related to the willingness of the followers, work maturity is related to the followers" skills and competencies (Cherry, 2018; Graeff, 1983). Depending on the various combinations of these two maturity levels, four different maturity levels are formed. And depending on the different levels of followers' maturity, four different appropriate leadership styles were put forward (Gordon, 1991). When it is considered in terms of psychological and work maturity if the followers are mature, effective leadership style is delegating style and if the followers are immature, effective leadership style is telling style. If the followers' maturity level is moderate, then effective leadership styles are selling and participating styles (Cheryy, 2018). The model is presented in Table 2 in detail. Finding of Path-Goal Theory: in cases where tasks are uncertain and stressful, directive leadership leads to high job satisfaction. Supportive leadership results in high job satisfaction and performance when tasks are certain (structured) and planned. When a directive leadership style is applied to employees with high experience and competence, the reluctance of employees emerges. While tasks are uncertain and complex, participative leadership is the most effective leadership if group members expect clarity and autonomy.

While the tasks are uncertain and complex, the achievement-oriented leadership style is determined as the most effective leadership if the expectations of the group members are high. The roots of the pathway theory developed by Robert House (1971) based on expectation theory (Gordon, 1991). According to 
the theory, it is the leader's duty to provide information, support or other resources to achieve the objectives of the organization.

Table 2. Hersey-Blanchard Situational Leadership Model

\begin{tabular}{|c|c|c|c|c|}
\hline $\begin{array}{c}\text { Maturity } \\
\text { Levels }\end{array}$ & $\begin{array}{c}\text { Follower } \\
\text { Behaviours }\end{array}$ & $\begin{array}{c}\text { Psychological and } \\
\text { Work Maturity }\end{array}$ & Leadership Styles & $\begin{array}{c}\text { Leadership } \\
\text { Behaviours }\end{array}$ \\
\hline Mature & $\begin{array}{c}\text { Willing } \\
\text { Can }\end{array}$ & $\begin{array}{c}\text { Psychological maturity (+) } \\
\text { Work maturity (+) }\end{array}$ & $\begin{array}{c}\text { Delegating. Planning and } \\
\text { execution authorities are given to } \\
\text { followers }\end{array}$ & $\begin{array}{c}\text { Low R-O } \\
\text { Low T-O }\end{array}$ \\
\hline Moderate & $\begin{array}{c}\text { Willing } \\
\text { Can not }\end{array}$ & $\begin{array}{c}\text { Psychological maturity (+) } \\
\text { Work maturity (-) }\end{array}$ & $\begin{array}{c}\text { Participating. Leader includes } \\
\text { followers in decision making }\end{array}$ & $\begin{array}{c}\text { High R-O } \\
\text { Low T-O }\end{array}$ \\
\hline Moderate & $\begin{array}{c}\text { Unwilling } \\
\text { Can }\end{array}$ & $\begin{array}{c}\text { Psychological maturity (-) } \\
\text { Work maturity (+) }\end{array}$ & $\begin{array}{c}\text { Selling } \\
\text { Leader explains ideas to followers }\end{array}$ & $\begin{array}{c}\text { High R-O } \\
\text { High T-O }\end{array}$ \\
\hline Immature & $\begin{array}{c}\text { Unwilling } \\
\text { Can not }\end{array}$ & $\begin{array}{c}\text { Psychological maturity (-) } \\
\text { Work maturity (-) }\end{array}$ & $\begin{array}{c}\text { Telling } \\
\text { The leader gives orders to } \\
\text { followers }\end{array}$ & More T-O \\
\hline
\end{tabular}

Note: R-O: Relationship oriented, T-O: Task-oriented.

Source: compiled by the author.

Effective leaders set goals, clarify the path to the goal, and reward the followers when the goal is achieved (House, 1971). Whether the goals are specific, whether the path to the goal is clear and whether there is an award for the follower after reaching the goal affect the effective leadership style. Therefore, the structure of the tasks and followers' expectations based on their qualifications can be specified as the conditions that determine the leadership effectiveness. In theory, four different leadership styles were put forward: directive, supportive, participative and achievement-oriented (Daft et al., 2010; Robbins, 2001; Griffin, 1990). Thus, in cases where tasks are uncertain and stressful, directive leadership leads to high job satisfaction. Supportive leadership results in high job satisfaction and performance when tasks are certain (structured) and planned. When a directive leadership style is applied to employees with high experience and competence, the reluctance of employees emerges. While tasks are uncertain and complex, participative leadership is the most effective leadership if group members expect clarity and autonomy. While the tasks are uncertain and complex, the achievement-oriented leadership style is determined as the most effective leadership if the expectations of the group members are high (Daft et al., 2010; Robbins, 2001; Griffin, 1990).The most prominent criticisms directed to contingency theories are that they lack adequate research in order to test assumptions of theory and fail to account for how certain demographic characteristics affect the leader-subordinate relations (Shonhiwa, 2016). After the impact of contingency leadership on explaining leadership began to increase, many new leadership styles have emerged. It is possible to express some of these leadership styles as political leadership, entrepreneurial leadership, paternalistic leadership, servant leadership and collaborative leadership. Although, for instance, the paternalistic leadership emerged in the $80 \mathrm{~s}$, it can be stated that it reflects the characteristics of situational leadership theory since in paternalistic leadership, the effectiveness of the paternalist leader depends on the cultural values of the followers. On the other hand, many of these emerging leadership styles, which include the basic assumptions of contingency leadership theory, have been criticized. The basis of this criticism lies in the fact that the new styles do not say anything different from the old leadership styles. This situation can also be accepted as a criticism of contingency leadership theory.

Conclusion. In this study, the prominent theories in the literature which explain leadership with different perspectives have been examined, researches and models contributing to each leadership theory have been summarized and a general overview of leadership theories has been presented. Leadership theories were classified, and the fundamental assumptions and criticisms of each theory were analysed 
with a critical perspective. Accordingly, it can be argued that the great men, trait and behavioural theories have universal assumptions and the theories which emerged after these theories are contingent. It should be noted that there is no clarity in the literature regarding the classification of leadership theories. For instance, in some studies, universal leadership theories are called classical leadership theories, while contingency leadership theory is called as modern leadership theory. It can be stated that in many sources, the great men theory has not been discussed and presented separately, but it has been discussed within the trait theory. Although they have common characteristics, these are two different theories in terms of their assumptions. While great men theory claims that the leader characteristics are innate (Kirkpatrick and Locke, 1991), trait theory reveals that the leader characteristics can be both innate and subsequently acquired (Pierce and Dunham, 1990). This shows that the two theories are separate from each other. In the literature, it can be assumed that there is complexity about these theories. When the criticisms directed to the great men theory are examined, it is emphasized that it includes a gender-based prejudice (Spector, 2016). This criticism is acceptable, but it should be taken into consideration that women were not active in areas that would lead to the flow of life when great men theory was developed. This can be regarded as a heavy criticism for the theory. Both great men and trait theories have been criticized for lack of scientific research and tests (Harrison, 2018). Although these two theories are criticized for lack of scientific research, they are accepted as the first theories in which leadership was examined scientifically. In fact, this is a subject for major criticism. Because it is a great contradiction to scientifically judge these theories, which are supposed to be the first theories to be examined scientifically. The inconsistent findings obtained in the studies contributing to the trait theory (Schriesheim et al., 2001) led to suspicions about the validity of the theory and paved the way for the emergence of behavioural theory. Behavioural theory, in contrast to the great men and trait theories, rejected the leadership characteristics and sought to explain leadership by behaviours. In research and models contributing to the development of behavioural theory, the focus mostly on employee-oriented and task-oriented behaviours in defining effective leadership has been emphasized and some findings have been reached that are supposed to be universal. The criticism of great men, trait and behavioural theories is that they do not consider situational and environmental factors. Moreover, when all the theories including contingency theory are examined, the biggest criticism can be directed to the fact that a huge proportion of the leadership theories are of North American origin. The assumption that the findings of these researches in North American origin are valid in all parts of the world requires considering all theories with suspicion (Pasa, et al., 2001). For instance, the cultural values of North American people are generally individualistic, achievement-oriented and low in power distance. But these are not the value of all people in the rest of the world. For this reason, it is necessary to consider these theories with suspicion. When new leadership approaches revealed recently are examined, it can be assumed that the contingency theory still has a strong effect. In this sense, culture has been added to leadership research as an important condition and it has been evaluated that effective leadership may change from culture to culture. For instance, contrary to western society, paternalist leadership is assumed to be compatible with the cultural values of eastern societies. In addition, there may be more than one hundred leadership styles today. These new types of leadership, in fact, do not say much about anything new outside of the old ones and are limited to repeating each other. For instance, all entrepreneurial leadership, collaborative leadership, authentic leadership or charismatic leadership styles emphasize that leaders should have a vision in terms of effectiveness, be closely involved with followers and be sensitive to the environment. These abovementioned characteristics do not clearly distinguish leadership styles from each other. Because it is already expected that a leader must have a vision, be sensitive to the environment and engage with the followers. It is possible to interpret the main reason for the emergence of self-repetitive leadership styles as an effort to create something new away from scientific concerns. But this situation may lead to problems such as divergence from main theories and meaninglessness. Although there have been many developments in the leadership field, it should not be forgotten that 
theoretical integration has not been completed yet (Deure et al., 2011; Avolio, 2007). In this study, only the prominent theories in the literature are examined. On the other hand, for instance, skill theory or new leadership approaches that have emerged after contingency theory have not been included in the study. This can be considered as a limitation of the study. In this context, future researches can focus on new leadership approaches and the assumptions; and research or findings of these approaches can be interpreted with a critical point of view. Since theoretical integration in leadership has not been yet fully achieved, there is still a need for studies aiming to summarize leadership theories in general. In this sense the evaluation of theories from a critical point of view is pivotal.

\section{References}

Allio, R. J. (2013). Leaders and leadership-many theories, what advice reliable? Strategy and Leadership, 41(1), 4-14. Amanchukwu, R.G. Stanley, G. J. \& Ololube, N. P. (2015). A review of leadership theories, principles and styles and their relevance to educational management. Management, 5(1), 6-14.

Avolio BJ. (2007). Promoting more integrative strategies for leadership theory-building. American Psychologist, 62, 25-33

Barling, J., Christie, A., \& Hoption, C. (2011). Leadership. In S. Zedeck (Ed.), APA handbook of industrial and organizational psychology, Vol 1: Building and developing the organization. APA Handbooks in Psychology. (pp. 183-240). American Psychological Association.

Bennis W. G. (2007). The challenges of leadership in the modem world-Introduction to the special issue. American Psychologist, 62, 2-5.

Billig, M. (2015). Kurt Lewin's leadership studies and his legacy to social psychology: is there nothing as practical as a good theory? Journal for the Theory of Social Behaviour, 45(4), 440-460.

Bolden, R., Gosling, J., Marturano, A. \& Dennison, P. (2003). A review of leadership theory and competency frameworks. Edited version of a report for Chase Consulting and the management standarts centre, Exeter, UK.

Carlyle, T. (1993). On-Heores, Hero-Worship, and the Heroic in History. An Electronic Classics Series Publication.

Cherry, K. (2018). Situational leadership theory. Retrieved from: https://www.verywellmind.com/what-is-the-situational-theoryof-leadership-2795321.

Daft, R. L., Kendrick, M. \& Vershinina, N. (2010). Management. Cengage Learning Emea, UK

Derue, D. S., Nahrgang, J. D., Wellman, N. \& Humprey, S. E. (2011). Trait and behavioral theories of leadership: An integration and meta-analytic test of their relative validity. Personnel Psychology, 64, 7-52.

Fiedler, F. E. (1975). The leadership game. Matching the man to the situation. Organizational Dynamics, 4(3), 6-16.

Fiedler, F. E. (2006). The contingency model: a theory of leadership effectiveness. In Levine, J. M. \& Moreland, R. L. (Eds.), Small Groups Key Readings, Psychology Press, New York.

Fleeor, J. W. (2006). Trait approach to leadership. Encyclopedia od Industrial and Organizational Psychology, Sage Publications

Flocy, J. (2017). Responsible leadership: A behavioural perspective. Doctoral Dissertion Submitted to Lee Kong Chian School of Business.

Gill, R. (2011). Teory and practice of leadership (2nd ed.). London: Sage.

Goff, D. G. (2003). What do we know about good community college leaders: A study in leadership trait theory and behavioral leadership theory. (Report No. JC 030 281). Tampa, FL: Hillsborough Community College. (ERIC Document Reproduction Service No. ED476456).

Gordon, J. R. (1991). A Diagnostic Approach to Organizational Behavior. Allyn and Bacon, Usa.

Graeff, C. L. (1983). The situational leadership theory: a critical view. Academy of Management Review, 8(2), 285-291.

Griffin, R. W. (1990). Management. 3rd Edition, Houghton Mifflin Company, Boston, Usa.

Grint, K. (2011). A history of leadership. In: Bryman A, Colinson D, Grint K, et al. (eds) The Sage Handbook of Leadership. Los Angeles: Sage, 3-14.

Harrison, C. (2018). Leadership Research and Theory. In: Leadership Theory and Research. Palgrave Macmillan, Cham.

House, R. J. (1971). A path-goal theory of leader effectiveness. Administrative Science Quarterly, 16, 321-338.

House, R. J., \& Aditya, R. N. (1997). The cocial scientific study of Leadership: Quo vadis? Journal of Management, 23, $409-473$.

Jago, A. G. (1982). Leadership: Perspectives in Theory and Research. Management Science, 28(3), 315-336.

Johns, H. E. \& Moser, H. R. (2001). From trait to transformation: the evoluation of leadership theories. Education, 110(1), 115-122.

Judge, T. A., Bono, J. E., llies, R. \& Gerhardt, M. G. (2002). Personeality and leadership: A qualitative and quantitative review. Journal of Applied Psychology, 87(4), 765-780

Kirkpatrick, S. A. \& Locke, E. A. (1991). Leadership: do traits matter? Academy of Management Executive, 5(2), 48-60. $5-13$.

Kraft, M. H. G. (2018). Antecedents\&Perspectives of Ambidextrous Leadership. Marketing and Management of Innovations, 4 , 
Lewin, K., Lippert, R., \& White, R. K. (1939). Patterns of aggressive behavior in experimentally created social climates. Journal of Social Psychology, 10(2), 271-301.

Likert, R. (1979). From production-and employee-centerednes to systems 1-4. Journal of Management, 5, 147-156.

Mann, R. (1959). Leadership Theory and Practice. In Northouse, P. Thousand Oaks, CA: Sage Publishing.

Mirzoeff, N. (2006). On visuality. Journal of Visual Culture, 5(1), 53-79.

Northcraft, G. B. \& Neale, M. A. (1990). Organizational Behavior A Management Challenge. The Dryden Press, Usa.

Northouse, P. G. (2010). Leadership: Teory and practice (5th ed.). Tousand Oaks: CA: Sage.

Pasa, S. F., Kabasakal, H., \& Bodur, M. (2001). Society, organizations, and leadership in Turkey. Applied Psychology: An International Review, 50, 559-589.

Pierce J. L. \& Dunham, R. B. (1990). Managing. Scott, Foresman/Little, Brown Higher Education, London, England.

Robbins, S. P. \& T. A. Judge. (2012). Örgütsel Davranış 14. Basımdan Çeviri, Ed. Erdem, I. Nobel Yayıncilık.

Robbins, S. P. (2001). Organizational Behavior. 9th Edition, Prenctice Hall International, New Jersey.

Rue, L. W. and L. L. Byars (1990). «Supervision». 3rd Edition, Irwin, Boston.

Schriesheim, C. A., Tolliver, J. M. \& O. C. Behling (2001). Leadership Theory: Some Implications for Managers in Dynamics of Leadership, ed. C. M. Watson, Jaico Publishing House, Mumbai.

Seigel, J. P. (1995). Thomas Carlyle. Routledge, London and New York.

Shonhiwa, D. C. (2016). An Examination of the Situational Leadership Approach: Strengths and Weaknesses. Cross-Currents: An International Peer-Reviewed Journal on Humanities \& Social Sciences, 2(2), 35-40.

Sprector, B. A. (2016). Carlyle, Freud, and the Great Man Theory more fully considered. Leadership, 12(2), 250-260.

Stogdill, R. M. (1948). Personal factors associated with leadership: A survey of the literature. Journal of Psychology, 25, 35-71. Stogdill, R.M. (1974). Handbook of leadership: A survey of the literature, New York: Free Press.

Van Wart, M. (2003). Public-sector leadership theory: An assessment. Public Administration Review, 63(2), 214-229.

Yukl, G. (1989). Managerial leadership: a review of theory and research. Journal of Management, 15(2), 251-289.

\section{O. Услу, D.Sc., Університет Сакар'я (Туреччина).}

\section{Концептуальні засади теорій лідерства: критичний аналіз}

Феномен лідерства викликає науковий інтерес та дискусію серед дослідників різних наукових напрямів. Так, наразі значну кількість досліджень присвячено вивченню питань теорії лідерства. Не зважаючи на значний науковий доробок у цьому напрямі, світовою наукової спільнотою узагальнену теорію лідерства досі не прийнято. У зв'язку з цим, актуальним $є$ аналіз та систематизація теоретичних досліджень щодо теорій лідерства. Таким чином, виходячи із вищезазначеного, метою статті є дослідження традиційних та сучасних теорій лідерства, а саме: теорії видатної особистості, теорії лідерських якостей лідера, поведінкової теорії та теорії обставин. У ході дослідження автором запропоновано класифікувати теорії на універсальну теорію лідерства та теорію обставин. При цьому у статті систематизовано основні особливості, положення, недоліки зазначених теорій лідерства. Результати узагальнення та систематизації наукових напрацювань з визначеної проблематики свідчать, що теорії видатної особистості та лідерських якостей лідера відрізняються між собою, незважаючи на те, що у більшості наукових літературних джерел вищезазначені теорії розглядаються як єдине ціле. Автор обгрунтовує недосконалість та неефективність теорії видатної особистості, оскільки вона не враховує гендерний фрактор. У статті визначено, що теорія видатної особистості та теорія лідерських якостей лідера - перші теорії, в яких лідерство досліджено та описано із наукової точки зору. При цьому автором наголошено, що світова наукова спільнота не має єдиної точки зору, які саме теорії першими розкрили сутність лідерства з наукової точки зору. Результати аналізу показали, що значна частка теорій лідерства, включаючи теорію обставин, має Північноамериканське походження, що обумовлює появу протиріч за умови їх використання в інших частинах світу. Автором визначено, що наразі використовується більще ста стилів лідерства, більшість з яких $\epsilon$ аналогами або модифікацією попередніх та повторюють один одного. У статmі представленні результати дослідження, що дають загальну характеристику сучасних та традиційних теорій лідерства з критичної точки зору. Автором наголошено, що отримані результати дослідження можуть слугувати відправною точкою подальшого розвитку наукової дискусії з питань теорій лідерства, організаційної поведінки та менеджменту.

Ключові слова: лідерство, теорія видатної особистості, теорія лідерських якостей лідера, поведінкова теорія, теорія обставин.

Manuscript received: 20.01 .19

(C) The author(s) 2019. This article is published with open access at Sumy State University. 